\title{
Sharing in God's surprise: The Place and role of the Department of Science of Religion and Missiology at the University of Pretoria
}

Author:

Pieter (Piet) G.J. Meiring ${ }^{1}$

\section{Affiliation:}

${ }^{1}$ Department of Science of Religion and Missiology,

University of Pretoria,

South Africa

\section{Correspondence to:}

Pieter (Piet) Meiring

e-mail:

pietmeiring@telkomsa.net

Postal address:

327 Camellia Ave,

Lynnwood Glen, Pretoria, 0081, Gauteng, South Africa

\section{Keywords:}

Department of Science of Religion and Missiology; University of Pretoria; mission; missiology; Dutch Reformed Church

\section{Dates:}

Received: 16 July 2009

Accepted: 29 Aug. 2009

Published: 17 Dec. 2009

How to cite this article: Meiring, P.G.J., 2009,

'Sharing in God's surprise: The place and role of the Department of Science of Religion and Missiology at the University of Pretoria', Verbum et Ecclesia 30(3), Art. \#183, 7 pages. DOI: $10.4102 /$ ve.v30i3.183

This article is available at:

http://www.ve.org.za

(C) 2009. The Authors. Licensee: OpenJournals Publishing. This work is licensed under the Creative Commons Attribution License.

\section{ABSTRACT}

During the centenary year of the University of Pretoria (2008), the Department of Science of Religion and Missiology took stock of its activities during the past 55 years, since the first professor in Missiology, H.D.A. du Toit, was appointed. In his wake a number of missiologists followed - C.W.H. Boshoff, D. Crafford, P.G.J. Meiring, J.J. Kritzinger, P.J. van der Merwe, A.S. van Niekerk and C.J.P. Niemandt - each of whom has contributed to the formation of hundreds of ministers and missionaries, as well as to the development of missiology and science of religion in South Africa through their research and writings. In this article, the place of missiology among the other theological disciplines at the University of Pretoria is discussed, together with an analysis of the nature and the mandate of missiology and science of religion in South Africa in our day. This article discusses five specific challenges to missiology at the beginning of the third millennium, namely to maintain its theological 'roots'; to operate in close relationship with the church; to focus on our African context; to concentrate on a relevant agenda; and to develop a responsible methodology. Attention is given to some of the more important publications by members of the Department.

\section{The first steps}

\section{INTRODUCTION}

Mission and missiology, it may be stated with gratitude, are given a high priority at the University of Pretoria. For more than 50 years, science of religion and missiology (or science of mission) has been accepted as an equal partner to the other disciplines in the Faculty of Theology. The roots of the Department of Science of Religion and Missiology go back to 1953, with the appointment of H.D.A. du Toit as first professor and head of the Department - a first in the annals of the Dutch Reformed Church (DRC). At the Theological Seminary at Stellenbosch University, professors J. du Plessis and G.B.A. Gerdener have given attention to the subject of mission over many years - they even published a number of important books in this regard - but an independent chair in Missiology was only created in 1958 with the appointment of W.J. van der Merwe. Prof. Du Toit's responsibilities at the University of Pretoria were far reaching. Together with science of religion and missiology, he was required to attend to the field of practical theology as well - which at the time was not yet accepted as an academic discipline. 'Way above the capabilities of a single person', was the sympathetic comment of Du Toit's New Testament colleague, E.P. Groenewald, at the time (Groenewald 1972:50, my translation).

\section{DEVELOPMENTS WITHIN THE DEPARTMENT}

During the 1950s, the DRC saw a renewed and growing enthusiasm for missions. Young people volunteered their services. Theological candidates, as well as ministers in a number of congregations, offered themselves to be sent out to the mission fields of the church - both inside and beyond the borders of South Africa. Local congregations pledged their support, spiritually as well as financially. The Faculty of Theology at the University of Pretoria was equally enthusiastic about its contribution in this regard, and had high hopes for Du Toit's role to inspire and empower his students for the cause. He succeeded in this - not only by providing a strong academic foundation for the Department - but also with his challenging lectures and the numerous missionary tours that he undertook with his students. It came as no surprise that a substantial number of his students ended up either in missionary ministries in the field, or as lecturers in Missiology in and outside South Africa. Two of his publications, Die kerstening van die Bantoe (The Christianisation of the Bantu) (1967) and Vyf godsdienste van die wêreld (Five world religions) (1970), drew much attention - locally as well as in the Netherlands.

When Du Toit was asked to chair the newly established Department of Practical Theology, C.W.H. Boshoff, missions director in the DRC (Southern Transvaal Synod), was appointed professor in Science of Religion and Missiology. With his years of experience in the field, as well as his academic prowess, Carl Boshoff did much to strengthen the Department. In 1976 the steady growth in student numbers mandated the appointment of a second professor. The choice fell on Dionne Crafford who, with his interest in mission history and his knowledge of Africa, left a significant imprint on the Department. When Boshoff reached retirement age, Crafford was appointed head of the department, with P.G.J. (Piet) Meiring at his side, to fill the vacancy. J.J. (Dons) Kritzinger, who initially was tasked with running the Department's Institute for Missionary and Ecumenical Research (IMER), joined forces with Crafford and Meiring. The three colleagues were in perfect balance. Crafford's expertise was mission history and African studies. Meiring's main interests were ecumenical relations, relations within the DRC family of churches, reconciliation studies and interfaith dialogue. Kritzinger launched one research project after the other, charting the DRC's way through the many challenges awaiting the church and its mission in our day. Together, the threesome took their students on tour in South Africa, as well as to Zimbabwe, Zambia, Botswana, Namibia, Swaziland and Lesotho.

When Crafford retired in 1994, Meiring was promoted to head the Department. When he, in January 1996, was appointed to serve in the South African Truth and Reconciliation Commission (TRC), Kritzinger became acting head of the Department. A.S. (Attie) van Niekerk (principal of the Stofberg 
Theological School, Turfloop) was invited to collaborate with Kritzinger, as researcher at IMER and as lecturer in Missiology. At the end of 1998 Meiring ended his stint at the TRC and rejoined the Department.

During the 1990s the fusion of the two faculties of Theology at the University of Pretoria, belonging to the Nederduitsch Hervormde Kerk (Section A) and the Nederduitse Gereformeerde Kerk (Section B) was on the cards. When the unification on 1 January 2000 was realised, P.J. (Piet) van der Merwe joined forces with his DRC colleagues. Van der Merwe's expertise was in the varied field of science of religion, which added important value to the curriculum. When Meiring reached retirement age in June 2007, C.J.P. Niemandt, an expert in American missiology with a specialist knowledge of the post-modern context of our day, was appointed.

When the Presbyterian Church of Southern Africa joined our Faculty, another step forward was taken. The presence of Presbyterian students as well as a growing body of students from other denominations - the majority of them being black Africans - served the Department well, opening new perspectives to lecturers and fellow students alike. The two newly appointed professors representing the Uniting Presbyterian Church Maake Masango, a practical theologian with a wide-ranging ecumenical experience, as well as Graham Duncan, a church historian with a comprehensive knowledge of the South African mission history - contribute in many ways to developments within our Department.

\section{MISSIOLOGY WITHIN THE FACULTY OF THEOLOGY}

\section{That the study of missiology at the University of Pretoria} deserved a permanent place within the theological curriculum goes without saying. Over many years, since the beginning of the 18th century, the DRC developed a strong missionary consciousness, which reflected on the training of ministers for the church. Furthermore, the DRC theologian David Bosch, our colleague from the University of South Africa (Unisa), reminded us time and again that mission should not only be accepted as part and parcel of theological studies, but has to be honoured as 'the mother of theology'. In his widely acclaimed Transforming mission, Bosch underlined this view with broad strokes (1991:15ff). The New Testament Church was primarily a missionary church, he wrote. Jesus left his disciples with the command to be his witnesses (Mt 28:19; Ac 1:8) and they obeyed by spreading the gospel far and wide. Everything they did, taught and wrote, has to be seen in a missionary perspective, Bosch argued. The first history of the church was mission history, the first theology no less than missionary theology. The authors of the New Testament, the first theologians, lived in an 'emergency situation' and were, because of their missionary encounter with the world, forced to theologise. Bosch was not the first to point to the importance of mission to the church and to theology - in the past as well as in the present. In developing his argument he gratefully pointed to Martin Kähler, Heinrich Kasting, Fiorenza and others, who over the years had come to the same conclusions (Meiring 1998:318ff).

Today, missionaries and missiologists across the globe are in general agreement with Bosch's sentiments. The same, however, does not necessarily apply to their colleagues in the other theological disciplines. For more than 1800 years the church would be busy practising its mission, before serious academic and scientific reflection on the mission of the church was included in the curricula of theological faculties and seminaries. The history of this process was carefully recorded by the Norwegian missiologist O.G. Mycklebust, in the two volumes of his The study of missions in theological education (1955/1957). Evidently, it has been an arduous process, before the theological 'daughters' were willing to acknowledge their 'mother'. Over the years a number of solutions to the problem of finding a suitable place for missiology/science of mission in the theological curriculum were offered (Meiring 1998:319).

A first solution was to include missiology within one of the other accepted theological disciplines: biblical studies, dogmatics, church history or practical theology. In Schleiermacher's view, missiology had to be placed within practical theology. Kuyper, Bavinck, as well as the Roman Catholic theologian Rahner, were of a similar opinion. In later years Schleiermacher argued that mission should be included within the study of theological ethics as well - seeing that mission constituted one of the cultural mandates of the church. In England, John Forster argued for the inclusion of missiology in church history, a view that was enthusiastically shared by C. Mirbst and the renowned American church historian K.S. Latourette. Yet another possibility, championed by H. Diem and Walter Holsten, was to find a place for missiology within systematic theology (dogmatics), especially within the rubrics of the Trinity of God and of eschatology. The South African systematic theologian, J. Alex van Wyk, also argued that mission needed to be included within dogmatics, preferably within the rubric of ecclesiology (Meiring 1998:319).

A second solution was to place missiology in its own right within the theological curriculum. This however, would mean that the traditional division of theology into the four classical disciplines - bibliological, dogmatological, ecclesiological and diaconological studies - would be abandoned, which was unacceptable to many. However, as a result of the growing enthusiasm for missions during the 19th century in Europe and the USA, pressure mounted on the universities and seminaries to include missiology/science of mission as a theological discipline in its own right in their curricula. Charles Beckenridge was the first lecturer to be appointed in science of mission and pastoral theology (Princeton, 1836). The first fulltime professor in what was called 'Evangelistic Theology' was the renowned Scottish missionary pioneer, Alexander Duff (New College, Edinburgh, 1867). In the same year, Carl Plath in Germany and Rufus Anderson in the USA commenced with academic visits to a number of universities, giving lectures in science of mission. The onus however, came to rest on Gustav Warneck, professor at the University of Halle (1896-1910) to lay the foundations for the wide acceptance of science of mission as a discipline in its own right. In 1910 Joseph Schmidlin was appointed as the first Roman Catholic professor in Science of Mission in Munster (Meiring 1998:320).

After the success of the first International Missionary Conference in Edinburgh 1910, missionary fervour in Europe and in America increased and a growing demand for missiological training at universities and seminaries had to be met. Numerous institutions appointed lecturers in science of mission. Missiologists from Europe and America, also from a number of Third World countries, contributed to the development of their discipline and made their presence felt at the universities and seminaries where they served. Sadly, at the end of the 20th century, with the steady decline of many churches in Great Britain and on the continent of Europe, enthusiasm for science of mission at British and European universities started to wane. In Germany, the Netherlands and in the United Kingdom, where only decades ago numerous influential missiologists attracted students from all over the world, a mere handful of lecturers - working in a ever diminishing number of mission departments - are desperately trying to keep the discipline alive. Not everything is lost, however. The recent decision taken by the Anglican Communion in the United Kingdom to appoint a commission to facilitate the reinstatement of missiology in the theological curriculum offers some hope for the future of the discipline in Great Britain

Speaking of Britain, during the 1980s a third possibility for accepting missiology in the theological curriculum was tabled: Missiology should not be taught as a separate subject, but should be integrated into every aspect of theological training. Every 
theological discipline should discover and develop its missionary dimensions. Cracknell and Lamb, however, have argued that no matter how high the expectations were, the programme eventually rendered limited results. To require of lecturers in the different fields of theology - who are already overburdened by the increasing demands made to them on a daily basis - to research the missiological perspectives and dimensions of their respective fields was seemingly asking for too much (Cracknell \& Lamb 1986:26).

In the theological training of the DRC, as stated above, a definite decision had been taken half a century ago to establish missionary departments in each of the three faculties of Theology connected to the church. At the University of Pretoria it happened in 1953, at Stellenbosch University in 1958 and at the University of the Free State in 1981. In recent years - at Stellenbosch - missiology was grouped together with practical theology in one department. How this will impact on the further development of missiology at that university remains to be seen. In our Department we are very grateful for the resolve of the University of Pretoria, as well as the governing bodies of the churches, to maintain a separate Department of Science of Religion and Missiology intact. While at many institutions worldwide our discipline is under considerable pressure, we want to do our utmost to serve the University and the church by practising our discipline as comprehensively and as conscientiously as we are able to.

\section{THE UNIQUE NATURE AND MANDATE OF MISSIOLOGY}

The question may well be asked: What is the real nature and task of missiology? What has missiology on offer to theology as well as to the church? The answer provided by Dionne Crafford in his inaugural lecture as head of the Department some years ago (1989) is still applicable. According to him, missiology has a threefold mandate:

- Missiology, firstly, has an integrating function. Quoting the Dutch missiologist $H$. Bergema, Crafford argued that missiology should be regarded as an ellipse within a wider ellipse, binding the other theological disciplines to one another. The different subsections of missiology can easily connect with the traditional theological departments: Missionary Theology with Biblical Studies, Missionary Theory with Systematic Theology and Missionary Methods with Practical Theology. This integrating function, Crafford said, is but one and arguably not the most important of the mandates of missiology.

- Missiology, in the second instance, has a corrective and a complimentary function. The German missiologist Manfred Linz often referred to missiology as a 'KomplimentärWissenshaft', which has the obligation to highlight the missionary dimensions in the other theological disciplines and to take care that these dimensions receive proper attention within the study of the Old and New Testament, dogmatics, ethics, church history and practical theology. Jo Verkuyl in the Netherlands, J.A. Sherer in the USA and David Bosch in South Africa were in total agreement on this point. Missiology has a perennial critical function, acting like leaven within the wider field of theology. The process, it must be noted, works in both ways: Missiology has an equal obligation to find answers to the questions posed to it by the other theological disciplines. But, Crafford contended, this second mandate - the accompanying function of missiology - should also not be regarded as the primary task of missiology. The implication of the latter would be that missiology's first focus should be on theology, and that may never be the case. Missiology's first focus should always be the world - not the church or, for that matter, theology!

- Thirdly, Crafford discussed the directive function of missiology, in his opinion the primary task of the discipline. With the results available from the study of the Old and New Testaments, dogmatics, church history and practical theology in hand, missiology's focus is on the world with all its needs and challenges, on all the nations to whom the Lord has sent his church. The gospel in all its dimensions and with all its implications has to be proclaimed to all people, in the different contexts in which they find themselves. This process of the church crossing the many borders - language, cultural, religious, geographical, political, economical, social and intellectual - is so important, so difficult and so fascinating that it merits a theological discipline in its own right.

\section{MISSIOLOGY IN THE FACULTY OF THEOLOGY AT THE UNIVERSITY OF PRETORIA}

How do we practice missiology at the University of Pretoria? How do we subdivide the discipline?

Missiology is firstly our reflection on God's acts of salvation in the world. The triune God is at work in the world. He is building his Kingdom among the nations, declaring Christ's Lordship in every sphere of life. Studying this process is done under the heading of mission theology.

Missiology is secondly tasked to research and describes the different ways in which God's salvation is being realised in the world, in the past as well as in the present. The story of how people are brought to faith in Christ, of how churches are built and of how signs of his Kingdom are erected on six continents, needs to be told. All of this is on the agenda of mission history.

The third assignment of missiology is to discover and develop the most effective ways and methods by which the Gospel of Jesus Christ may be carried to all nations by his church, who has the obligation not only to gather the believers into the one body of Christ, but to empower them to be witnesses of Christ's love and care for the world, by word and in deed. This is done under the rubric of missionary methods and practice.

Finally, missiology is tasked to provide a theological evaluation of the non-Christian religions and of the dialogue with adherents of these religions. The same applies to ideologies that acquire religious dimensions. This constitutes the terrain of the theology of religion(s).

\section{SCIENCE OF RELIGION AT THE FACULTY OF THEOLOGY}

Missiology and science of religion are twinned at the Faculty of Theology. Within the ranks of the Nederduitsch Hervormde Kerk, much attention traditionally had been given to science of religion, and with the merging of the two faculties of Theology and the two departments of Science and Religion and Missiology, research and tuition in the field of science of religion received a substantial boost. Piet van der Merwe is widely respected by his peers as an expert in this field and both his colleagues in the Department and his students profited from his specialised knowledge. Much has been written in the past on the proper relationship between missiology and science of religion - and the final word has not been said yet. Strictly speaking, science of religion is not to be regarded as a (Christian) theological discipline and should best be taught in a faculty of humanities, rather than in a theological faculty. This is indeed the case at a number of universities worldwide - also at Unisa. For practical reasons we chose to retain science of religion and missiology within our Faculty of Theology. We do however teach a number of courses for non-theological students, together with our colleagues in the Department of Biblical Studies and Religion, within the Faculty of Humanities. In South Africa, with its many religions, there is a growing interest in religion as phenomenon, as well as in the different religions of our fellow South Africans.

We do feel a grave responsibility as well towards our theological students to introduce them to the study of religion (theologia 
religionis, theologia religionum, philosophy of religion, phenomenology of religion) and to the study of the non-Christian religions in South Africa (the history of religions). Although we, as lecturers, strive to be as objective and scientific as possible in our presentation of the modules on Islam, Judaism, Hinduism, Buddhism and African religion, we realise that it is difficult to remove our Christian 'hats'. We acknowledge the problem, and strive to be as neutral as possible, regularly inviting representatives from the Muslim, Jewish, Hindu, Buddhist and traditional African religious communities to evaluate our course material and to address our students. Regular visits to mosques, synagogues and temples form part of the syllabi.

\section{MISSIOLOGY FOR THE THIRD MILLENNIUM: THE FIVE-FOLD CHALLENGE}

Practising missiology in the varied context of our world at the onset of the 21st century is no easy task. In his inaugural lecture as head of the Department (1995), Piet Meiring referred to five challenges in this regard (Meiring 1999b:141ff):

\section{A theological basis}

The theological basis of missiology, the vantage point of our discipline, has come under close scrutiny in recent years. In the new democratic South Africa, many a critical question has been asked about the existence of denominational theological faculties at state-subsidised universities in the country. Among the disciplines taught at these faculties, missiology often raises serious eyebrows. Kobus Krüger, professor in Science of Religion at Unisa, did not mince his words: 'Non-Christians had (and still have) the dubious privilege of having their taxes funneled into faculties and departments aimed at converting them from their own religion. This sounds like a sick joke. It is, to put it bluntly, a monopolistic and discriminatory arrangement' (Kruger 1994:16). Klippies Kritzinger, Kruger's colleague in the Department of Missiology at Unisa, was of a similar opinion, calling for the institution of a 'neutral' missiology department where the missionary activities not of one, but of all religions, are researched and taught. Christianity is not the only 'missionary faith', he contended. Muslims, Jews, Hindus and Buddhists have a message to share with others. They too want to help build a better - a more just - society. They too want to campaign for the integrity of creation. In short, everything that appears on the traditional Christian mission agenda applies to them as well. A healthy osmosis between the different faiths would serve us all! 'I suggest that Missiology should no longer focus exclusively on Christian mission, but widen its focus to include the missions of various religions' (ibid. 1994:16).

With due respect to our colleagues in South Africa and abroad who opt to practice theology on an interdenominational - even an interreligious - basis, our choice is still to function within a Christian faculty of theology, teaching missiology within the contours of our faith. We share the view of David Bosch, doyen of modern missiologists: 'Missiology as a branch of the discipline of Christian theology is not a disinterested or neutral enterprise; rather, it seeks to look at the world from the perspective of commitment to the Christian faith' (Bosch 1991:9). This, however, does not mean that missiology should be practised in an arrogant, paternalistic, discriminatory manner, with scant appreciation of the views and values of members of other faith communities. On the contrary, we need to enter into a dialogue with people of other faiths with respect. But in all humility, we cannot but confess with Paul, the greatest missionary of the Church: 'we proclaim Christ, crucified' (1 Cor 1:23). We do not regard ourselves above others. Instead, we are no more than beggars in the market place among other beggars. The only difference is that we have found bread to eat and want to share our gift with others.

\section{Connected to the church}

The second vantage point goes beyond the first: Missiology does not only need a Christian basis, it needs a strong connection to the church. Missiology can never be isolated from the church. Mission, by definition, does not only rest upon the Missio Dei (God's mission), but also on the missio ecclesiae (the mission of the church). Missiology has to guide the church in its mission, sensitive to the needs of the church on its way through the world. Every denomination needs motivated, well-trained missionaries, as well as ministers with a vision for mission, committed to the building of missional churches wherever they are called to serve - and this need should be met by the theological curriculum. The church needs missiology, but missiology needs the church as well. Without the input of the church - from time to time also without the critical questions aired by the church - missiology will hardly be able to function. In the same manner that a medical faculty can never be without a hospital, a faculty of theology - and especially a department of missiology - is unable to operate without a dynamic relationship with the church. This relationship may become stressed from time to time. Loyal to the church, missiology has an inescapable obligation to the academic community as well, plying its research and teaching in the best possible scientific tradition. But managed properly, the tension that from time to time surfaces - has to surface - should be experienced as a creative tension benefiting all parties involved.

The Department of Science of Religion and Missiology has taken its relationship with the church, the denominations connected to the Faculty of Theology at the University of Pretoria and the ecumenical community - on local as well as international levels - seriously, resulting in a number of publications. Dionne Crafford and Dr Johannie Cronje (who served as the first director of IMER) produced a comprehensive two-volume history of the mission of the DRC inside and outside South Africa (Aan God die dank (Give thanks to God) (Part 1, Crafford 1981; Part 2, Cronje 1982). Crafford, together with Gustav Gous, edited an equally comprehensive handbook on ecumenism - a first in Afrikaans - entitled Een liggaam - baie lede (One body - many members) (1993). Dons Kritzinger, who wrote extensively on issues pertaining to the ministry in the younger churches in the DRC family, led a widely acclaimed research project on the unfinished missionary task of the Church in South Africa (Die onvoltooide sendingtaak in Suid-Afrika) (1988a). An English translation of the report was published, titled The South African context for mission (1988b). A follow-up report with Kritzinger, again as editor, entitled No quick fixes: The challenge of missions in a changing South Africa was presented to the South African churches in 2002. His latest publication as emeritus professor was Rethinking ministry (2007). In 1992, Piet Meiring joined forces with Stephan Joubert to edit a book on the role of the church in an ever-changing South Africa: Fokus op die kerk (Focus on the church). The latest publication, from the pen of our newest colleague Nelus Niemandt, is on the role of the church in a post-modern context: Nuwe drome, nuwe werklikhede (New dreams, new realities) (2007).

\section{Our context: Africa}

Missiology's main focus is on the world. Everywhere in the world, where boundaries are crossed, where the Good News of Jesus is proclaimed, missiology has a role to play. In the complex world of our times, with all the opportunities and challenges the church is facing, the agenda of missiology grows in volume and in intensity. It is evident, David Bosch argued, that a two-fold transformation process is on the cards. On the one hand the world is changed by the proclamation of the Gospel. On the other hand the church is being transformed by the world in which it operates. The title of Bosch's magnum opus refers to this two-fold process of change: Transforming mission (1991).

Above all we keep reminding ourselves in the Department of Science of Religion and Missiology that our context is Africa. Forty years ago, at the founding of the South African Missiological Society, Professor Willie van der Merwe (the grand old man of missions and missiology in South Africa) pleaded with his peers: 'Take Africa seriously! Keep your eyes wide open, research Africa's unique challenges, listen to what other 
[sic] have said and written about Africa, above all lend your ears to what Africans themselves have to say' (1968:9ff). Almost 30 years later, Klippies Kritzinger, in his inaugural lecture as head of the Unisa Department of Missiology (1995), reiterated the plea. The process of Africanisation is of prime importance to missiology - in fact to every discipline in theology in South Africa: 'We have no contribution to make to the worldwide debates in theology or religious studies, if we do not approach those debates from a position of being immersed in the context of this country and the continent of Africa. I am not advocating isolationism from the academic traditions of the North, but I am worried about the inability of our faculty as a whole to grapple with the realities of our African context'. Klippies Kritzinger's concern is shared by his peers in the Department of Science of Religion and Missiology at the University of Pretoria.

To hear the heartbeat of Africa implies not only listening to scholars and church leaders, but to listen to the voices of poets and storytellers, to sit with sculptures and painters, to allow the music of Africa to flood your being. Attie van Niekerk, with his many publications in this regard, keeps reminding us of this. In 2005, an International Arts and Reconciliation Conference and Festival was held at the University of Pretoria, coordinated from our Department, attended by numerous scholars and artists from across the globe who came to speak and to listen to one another. Piet Meiring chaired the organising committee, with a number of colleagues from the Faculty of Theology appearing in the programme.

In the publication programme of our Department, Africa appeared high on the agenda. C.W.H. Boshoff's report on the emergence of black theology (Swart teologie van Amerika tot in Suid-Afrika) (1980) was followed by Dionne Crafford's book on the unique challenges that Africa poses to the church: Uitdagings vir die kerk in Afrika (1988). Crafford also edited a widely acclaimed volume on early champions of the Gospel in our part of the world, titled Trailblazers of the Gospel: Black pioneers in mission history in Southern Africa (1991). Piet Meiring, who even before joining the Faculty had written a number of books on African Christianity - Stemme uit die swart kerk (Voices from the Black Church) (1975); Die Kerk op pad na 2000 (The Church en route to 2000) (1977); Die kerk in die nuwe Afrika (The church in the new Africa) (1979) and Afrika - die hamer, die kruis en die sekel (Africa - the hammer, the cross and the sickle) (1987) continued to publish articles on the churches in Africa. Attie van Niekerk's three books on the African context in which we are called to minister were read and discussed by many inside and outside of university circles: Dominee, are you listening to the drums (1982); Saam in Afrika (In Africa, together) (1992) and Anderkant die reёnboog (Beyond the rainbow) (1996).

\section{A relevant agenda}

Missiology is called to accompany the church on its way to proclaim the gospel of Christ to all the nations. At the onset of the 20th century, when missionary fervour was high, when the marching order of Edinburgh 1910 - 'the evangelisation of the world in this generation' - was sounded, missiologists were at hand to help, to plan, to motivate and to train candidates for the mission of the church. When, in the aftermath of World War II, mission became a complex and often controversial undertaking, when the legitimacy of the Christian mission was questioned, when the relationship between Christianity and the other world religions was in contention, missiologists were called upon to help find new answers and to plot new directions. In the 1980s and 1990s, when socio-economic, political, cultural and ecological problems threatened to tear the world apart, when tension between 'ecumenicals' and 'evangelicals' within the Protestant family hampered the church's witness in the world, missiology again had a role to play. When at the end of the century, the DRC arrived at the point where it - with humility - confessed the sin of apartheid and the heresy of providing a theological argument for the policy of separate development, colleagues from the missiology departments were at hand to share in the shame and to help plot a new course.

In a similar fashion, missiology, in years to come, will have to develop a relevant agenda. The Department of the Science of Religion and Missiology at the University of Pretoria operates with a comprehensive definition of mission, revolving around the four mandates of kerugma, koinonia, diakonia and leitourgia. In years to come, close attention will have to be paid to the difficult issues pertaining to the obligation to proclaim the Gospel to people from different cultures and backgrounds, to call people in the varied contexts in which they find themselves to faith in Christ (kerugma). In the same way, all aspects of koinonia planting churches, empowering new members, reaching out to fellow Christians, developing ecumenical relations - need careful research and deliberation. That the diaconal mission of the church (diakonia) - meeting the needs of millions of the poor, hungry, sick, oppressed and marginalised, trying to survive in a shrinking world with dwindling resources - will make heavy demands to the church and its mission and to missiology, goes without saying. In addition to all of this, the vital dialogue between Christians and people of other faiths calls for the warmest hearts and sharpest minds the Faculty of Theology can offer for years to come. This will be done in the conviction that all our endeavours are, in the final instance, to be seen as our act of worship of the triune God who has called us into his service (leitourgia).

It was with this in mind that Dons Kritzinger and Piet Meiring, together with their Unisa colleague Willem Saayman, published a handbook on missionary methods which was - and still is - used by a number of universities and seminaries inside and beyond the borders of South Africa. The first edition, You will be my witnesses (1984) was revised and expanded (On being witnesses) (1994). Piet Meiring edited a textbook on the different religions in South Africa, entitled Suid-Afrika, land van baie godsdienste (A world of religions: A South African perspective) (1996). On the issue of dialogue between the faith communities, a book entitled Christen in ' $n$ land met baie godsdienste (On being a Christian in a land of many religions) (2002) was authored by Meiring. Following the appointment of Meiring to the South African TRC, research in reconciliation studies - and related subjects - landed high on the Department's agenda. Meiring's Kroniek van die Waarheidskommissie (1999a) (A chronicle of the Truth Commission) attracted wide attention. Meiring was subsequently invited to lecture on the subject in a number of overseas countries. This being said, it must also be noted that mission is constantly in flux. New problems call for new answers! Fresh research leading to better understanding and to viable initiatives is of extreme importance - also to the staff of the Department of Science of Religion and Missiology.

\section{A responsible methodology}

The last challenge is that of developing a proper, effective and accountable methodology for doing missiology. The final question is not whether missiology deserves a place at the University or within the theological curriculum. It is rather: How should missiology be practised? If excellence is the motto of the University of Pretoria, it needs to be reflected, as well, in the work done in the Department. In short: We need to find a balance between the stringent demands of the academic community to which we belong and the very practical needs of the churches and the community outside the halls of academe that we are called to serve.

How to do that? From experience in a number of Third World countries, lessons may be learned. In past decades - in Latin America - the Theological Education by Extension (TEE) programmes have forced theology as well as missiology out of their comfort zones to bring education to the masses. Priests, pastors, church leaders and laity were invited into the process, 
to be taught in their local contexts where they lived and worked. Paulo Freire's book Pedagogy of the oppressed (1970) was - and still is - widely read and applied. Education, he insisted, should never be 'from above' - as if the lecturer possesses the knowledge and insight that must be handed down to the students. Rather, Freire said, education has to be seen as an interactive process where teacher and student learn from one another and enrich one another. In South Africa we still have a long way to go. The South African Council of Churches launched a project some years ago to adapt the TEE programme for local use - with limited success. We need to heed the call of Bengt Sundkler, the Swedish missiologist who worked in South Africa for many years: Theological education needs rethinking and a redefinition, not according to the specifications of the classical Western curriculum, but geared to the needs of the local church, of the world in which the church is called to serve, as well as the needs of the students who present themselves to be educated. Over the years the Department of Science of Religion and Missiology has given much thought to these challenges. Research projects inter alia on developing programmes for the empowerment of lay leaders have been undertaken by Dons Kritzinger (Rethinking ministry [2007]). But we still have a long way to go. We will have to think long and hard and as creatively as possible on these issues, to develop relevant curricula and responsible, accountable, methods of teaching.

\section{STUDYING THE CHURCH AS SURPRISE}

It is necessary for us at the centenary of the University of Pretoria to rethink the role of the Department in the past and present - as well as in the future. To practice missiology in our day and in our circumstances is indeed a privilege, albeit - in David Bosch's words - a hazardous undertaking!

Every branch of theology - including missiology - remains piecework, fragile and preliminary. There is no such thing as missiology, period. There is only missiology in draft. Missiologia semper reformanda est! Only in this way can missiology become not only ancilla theologiae, the handmaiden of theology, but also ancilla Dei mundi, handmaiden of God's world.

(Bosch 1991:496)

The final word is this: Doing missiology is a joyous undertaking! It allows one to share in God's great surprise in the world. Ivan Illich said it all:

[Missiology] is the science about the Word of God as the Church in her becoming; the Word as the Church in her borderline situations; the Church as surprise and puzzle; the Church in her growth; the Church when her historical appearance is so new that she has to strain herself to recognize [sic] her past in the mirror of the present; the Church where she is pregnant of new revelations for a people in which she dawns... Missiology studies the growth of the Church into new peoples, the birth of the Church beyond its social boundaries; beyond linguistic barriers within which she feels at home; beyond the poetic images in which she taught her children... Missiology therefore is the study of the Church as surprise.

(Illich 1974:6)

Sharing in God's surprise - studying the Church as surprise this indeed is what missiology is all about, also in the thinking of our Department.

\section{REFERENCES}

Bosch, D.J., 1991, Transforming mission, Orbis Books, Maryknoll. Boshoff, C.W.H., 1980, Swart teologie van Amerika tot in SuidAfrika, NG Kerkboekhandel, Pretoria.

Bühlmann, W., 1974, The coming of the Third Church, St Paul, Slough.

Cracknell, K. \& Lamb, C. (eds.), 1986, Theology on full alert, British Council of Churches, London.

Crafford, D., 1981, Aan God die dank, Part 1, NG Kerkboekhandel, Pretoria.
Crafford, D., 1988, Uitdagings vir die kerk in Afrika, UP Teologiese Studies No 8, NG Kerkboekhandel, Pretoria.

Crafford, D. (ed.), 1991, Trailblazers of the Gospel: Black pioneers in mission history in Southern Africa, IMER, Pretoria.

Crafford, D. \& Gous, G. (eds.), 1993, Een liggaam - baie lede, Verba Vitae, Pretoria.

Cronje, J.M., 1982, Aan God die dank, Part 2, NG Kerkboekhandel, Pretoria.

Du Toit, H.D.A., 1967, Die kerstening van die Bantoe, NG Kerkboekhandel, Pretoria.

Du Toit, H.D.A., 1970, Vyf godsdienste van die wêreld, NG Kerkboekhandel, Pretoria.

Freire, P., 1970, Pedagogy of the oppressed, Penguin, Harmondsworth.

Groenewald, E.P., 1972, 'Prof Dr H.D.A. du Toit: Lewe en werk', in B.J. Marais \& C.W.H. Boshoff (eds.), Rondom die prediking, n.p., NG Kerkboekhandel, Pretoria.

Illich, I., 1974, Mission and midwifery: Essays on missionary formation, Mambo Press, Gwelo (Gweru).

Jongeneel, J.A.B. \& Van Engelen, J.M., 1995, 'Contemporary currents in missiology', in F.J. Verstraelen, A. Camps, L.A Hoedemaker \& M. Spindler (eds.), Missiology: An ecumenical interpretation, n.p., Eerdmans, Grand Rapids.

Kritzinger, J.J., 1988a, Die onvoltooide sendingtaak in Suid-Afrika, ISWEN, Pretoria.

Kritzinger, J.J., 1988b, The South African context for mission, Lux Verbi BM, Cape Town.

Kritzinger J.J. (ed.), 2002, No quick fixes: The challenge of mission in a changing South Africa, IMER, Pretoria.

Kritzinger, J.J., 2007, Rethinking ministry, Bybelmedia CLF, Wellington.

Kritzinger, J.J., Meiring, P.G.J. \& Saayman, W.A., 1984, You will be my witnesses, NG Kerkboekhandel, Pretoria.

Kritzinger, J.J., Meiring, P.G.J. \& Saayman, W.A., 1994, On being witnesses, Orion, Halfway House.

Kritzinger, J.N.J., 2009, 'Faith to faith - missiology as encounterology', Verbum et Ecclesia 29(3), 764-790.

Krüger, J.S., 1994, From one to many, Unisa, Pretoria.

Meiring, P.G.J., 1975, Stemme uit die swart kerk, Tafelberg, Cape Town

Meiring, P.G.J., 1977, Die kerk op pad na 2000, Tafelberg, Cape Town.

Meiring, P.G.J., 1979, Die kerk in die nuwe Afrika, Tafelberg, Cape Town.

Meiring, P.G.J., 1987: Afrika - die hamer, die kruis en die sekel, De Jager-HAUM, Pretoria.

Meiring, P.G.J., 1996, Suid-Afrika, land van baie godsdienste, Kagiso, Pretoria.

Meiring, P.G.J., 1998, 'Sendingwetenskap vir die derde millennium, Deel I', Skrif en Kerk 19(2), 314-324.

Meiring, P.G.J., 1999a, Kroniek van die Waarheidskommissie, Carpe Diem, Vanderbijlpark.

Meiring, P.G.J., 1999b, 'Sendingwetenskap vir die derde millennium, Deel II', Skrif en Kerk 20(1), 139-149.

Meiring, P.G.J., 2002, Christen in 'n land van baie godsdienste, Lux Verbi BM, Wellington.

Meiring P.G.J. \& Joubert, S.J. (eds.), 1992, Fokus op die kerk, CUM, Vereeniging.

Mycklebust, O.G., 1955/1957, The study of missions in theological education, Egede Instituttet, Oslo (two tapes).

Niemandt, C.J.P., 2007, Nuwe drome, nuwe werklikhede, Lux Verb BM, Wellington.

Van der Merwe, P.J., 1992, 'Die resente geskiedenis en ontwikkeling van die Department Godsdiens- en Sendingwetenskap (Afd. A) 1979-1992', Hervormde Teologiese Studies 48/1\&2, n.p.

Van der Merwe, W.J., 1968, 'Die beoefening van sendingwetenskap in Afrika', in D.J. Bosch (ed.), Sendingwetenskap vandag, n.p., SAWS, Pretoria.

Van Niekerk, A.S., 1982, Dominee, are you listening to the drums?, Tafelberg, Cape Town

Van Niekerk, A.S., 1992, Saam in Afrika, Tafelberg, Cape Town. 
Van Niekerk, A.S., 1996, Anderkant die reënboog, Tafelberg, Cape Town.

Van Wyk, J.A., 1958, Die Apostolaat van die kerk, Kerk en Wêreld, Morija.
Woodberry, J.D., Van Engen, C. \& Elliston, E.J. (eds.), 1996, Missiological education for the 21st century, Orbis, Maryknoll. 